\title{
Ferns of Jamaica
}

\section{ELLSWORTH P. KILLIP}

The island of Jamaica has long been one of the paradises of the world for the fern collector. Here all the elements essential to a luxuriant fern growth seem to occur in just the right quantities. A constant supply of heat and moisture and an altitude ranging from sealevel to 7428 feet have resulted in the development of a large number of species.

The island is approximately 150 miles from east to west and 50 miles from north to south. A ridge of mountains runs from east to west through the center of the island and it is among these mountains that the greatest number of ferns are found. In my brief visit to Jamaica in the winter of 1916 , my fern collecting was chiefly confined to the mountainous regions of Cinchona and Hollymount.

Cinchona is the name given to a vast tract of land, ranging in altitude from 4500 feet to 6100 feet, embracing a portion of the Blue Mountain Range slightly to the northwest of Blue Mountain Peak. An unsuccessful attempt was made by the Jamaican government some years ago to introduce quinine (Cinchona) here. This was one of the tropical stations of the New York Botanical Gardens for some years. At the time of my visit it was unoccupied and the Director of the Public Gardens very kindly placed the several well-built buildings, including a laboratory, at my disposal.

Sir John's Peak, situated in the reservation, is the second highest mountain in the island. The trail leading from the buildings at 4900 feet altitude, to the summit, passes in part through dense, moist forests and in part skirts the sides of mountains through territory exposed to the sun's rays. At times the trail runs along windward slopes where conditions are particularly 
favorable to fern growth; at other times it follows the leeward slopes. On the trunks and branches of trees in the moist forests masses of Polypodia and Hymenophylla hang down, while various species of Diplazium and Asplenium are found as terrestrial plants. On the leeward slopes and in open situations Polystichum struthionis, Pteridium aquilinum, Histiopteris incisa, Pityrogramma calomelaena, as well as various species of Dicranopteris and Lomaria, occur. Tree-ferns, some of them reaching thirty feet in height, are common.

The three mile road to Morce's Gap in general resembles the more open portions of the trail to Sir John's Peak. Deep ravines, however, frequently occur and these are filled with a varied assortment of ferns. The trail gradually works its way to the windward side of the ridge, where another very fruitful region is found. Tree-ferns are particularly abundant at Morce's Gap.

In making the descent from Cinchona to Papine (about fifteen miles distant and at an altitude of about 1000 feet) the characteristic ferns found were Pityrogramma sulphurea and tartarea, Blechnum occidentale, Pteris longifolia, Anemia hirsuta, Notholaena trichomanoides, Cheilanthes microphylla, and Trismeria trifoliata. One of the two native species of Adiantum, (A. concinnum) found in this part of the island, was discovered a few miles east of Papine. These ferns also characterized the flora along the road to Newcastle.

A few days were spent at Hollymount (altitude, 2000 to 3000 feet) in the center of the island. Here the ferns for the most part were representatives of the genera Dryopteris, Polystichum, Adiantum, and Tectaria. The roadsides both here and at Moneague and St. Ann's Bay, later visited, were lined with Anemia adiantifolia and Adiantum tenerum. Occasionally unusual forms of Polypodium would be found, twining about trees and trailing over rocks. 
Over 500 species of ferns and fern-allies are recorded from Jamaica. Many of these are very local and but seldom collected. In the two weeks the writer spent in fern-bunting 137 species were found. In the list appended the stations given merely represent localities from which specimens were collected and are not to be considered as limiting the range of the species to those stations. Several sets were collected of which one has been presented to the United States National Museum, another to the Rochester Academy of Science, and a third to the American Fern Society. The writer still has on hand several specimens which he will be glad to exchange with members of the Fern Society.

In the Fern Bulletin of July, 1900, Mr. Willard N. Clute commenced the publication of a list of fernworts collected in Jamaica. Comparison of his list with mine is somewhat difficult, as recent study has resulted in the formation of new species and in alterations of genera. Eliminating certain genera in which these difficulties are particularly pronounced, together with Lycopodium and Selaginella of which I find no reference in the Fern Bulletin, we find that Clute's list records 193 species while mine has 118. His list contains about 112 species not found in mine, while mine contains about 37 not listed by him. About 80 species are common to both. Among the filmy ferns and in the genus Asplenium $\mathrm{Mr}$. Clute's net gain was especially large. In comparing these lists it must be remembered that his investigations covered the eastern portion of the island alone while mine extended over the central portion as well; on the other hand he spent considerably more time in the island.

Forrest Shreve, in a work entitled "A Mor tane Rainforest," published by the Carnegie Institute in 1914, gives a very detailed account of Cinchona and includes a list of the Pteridophytes he gathered there. A com- 
parison of his list of ferns with mine shows that he collected 90 species as compared with my 82 and that he gathered 43 not found by me, while I gathered 35 not found by him. Species common to both lists number 47.

In conclusion I wish to express my very great thanks to Mr. William Harris, Director of the Public Gardens of Jamaica, for his kindness in permitting me to stay at Cinchona and for the very *valuable aid which he rendered me in many ways, and to Mr. W. R. Maxon, of the United States National Museum, for making the determinations of the ferns.

\section{Hymenophyllaceae}

Trichomanes

1. T. CRispum L. A large species. Sir John's Peak, $5800 \mathrm{ft}$. (228)

2. T. Radicans Swartz. In dense woods. Pinnae variously cut. Morce's Gap and Hollymount. $(283,432)$

3. T. Rigidum Swartz. Along trail to Morce's Gap. (303)

\section{HyMENOPHYLLUM}

4. H. Aspleniordes Swartz. A delicate filmy fern with fronds but slightly cut. On trees, Sir John's Peak, 5900 ft. (312)

5. H. Fucoides Swartz. Not common. Growing on trees along the trail to Sir John's Peak, $5700 \mathrm{ft}$. (237)

6. H. polyanthos Swartz. A common fern on trees. There is great variation in the outline of the pinnae. $(237 \mathrm{a}, 296,304,313)$

7. H. SERICend Swartz. Common on trees along the Sir John's Peak trail and at Morce's Gap. It has very woolly fronds. 


\section{Cyatheaceae}

\section{Culcita}

8. C. Conirfolia (Hook.) Maxon. Along trail to Sir John's Peak, 5600 ft. (249a)

\section{Cyathea}

9. C. Furfuracea Baker. Common along the trail to Morce's Gap. (298)

10. C. Pubescens Mett. A large tree-fern. Morce's Gap. (287)

\section{Alsophila}

11. A. euadripinnata (Gmel.) C. Chr. Sir John's Peak, $5500 \mathrm{ft}$. (249)

\section{Polypodiaceae}

DRYOPTERIS

12. D. asplenioides (Swartz) Kuntze. Cinchona, about $5000 \mathrm{ft}$. (171)

13. D. asterothrix (Fée) C. Chr. Hollymount woods. (439)

14. D. cordata (Fée) Urban. A species which, according to Maxon, "is nowhere very common in the West Indies and decidedly uncommon in Jamaica." Hollymount. (469)

15. D. EFFusa (Swartz) Urban. Fairly common at lower altitudes. Content trail near Gordon Town. Hollymount. (336, 458)

16. D. Guadelupensis (Wikstr.) C. Chr. In crevices of rocks, Port Antonio. (536)

17. D. heteroclita (Desv.) C. Chr. Along the Morce's Gap trail about a mile north of the market-place. Sir John's Peak trail, $5100 \mathrm{ft}$. (214, 255)

18. D. hirta (Swartz) Kuntze. Hollymount woods. (430) 
19. D. normalis C. Chr. Along roadside near Papine. Hollymount woods. $(98,449)$

20. D. obliterata (Swartz) C. Chr. At Hollymount along the road to Moneague. But one specimen secured. (409)

21. D. Oligocarpa (Willd.) Kuntze. In Cinchona woods, $5000 \mathrm{ft}$. (261)

22. D. Patens (Swartz) Kuntze. Newcastle, about $2500 \mathrm{ft} . \quad(357)$

23. D. patula (Swartz) Underw. Morce's Gap. Not common. (625)

24. D. Reptans (Gmel.) C. Chr. Trail to Morce's Gap; Hollymount-Moneague road. A variable species, one form being found at Ewarton (485a) which is decidedly prostrate and with much shorter pinnae. $(306,485)$

25. D. sagittata (Swartz) C. Chr. Hollymoount woods. (421)

26. D. sancta (L.) Kuntze. Grows in thick clumps in dense woods near Hollymount. (439)

27. D. Serra (Swartz) Kuntze. Along road to Newcastle, about $2700 \mathrm{ft}$. (358). A form approaching D. oligophylla Maxon (503) was found at Roaring River Falls.

28. D. serrulata (Swartz) C. Chr. Along Hollymount-Moneague road. (483)

29. D. tetragona (Swartz) Urban. Frequent at lower altitudes. Along road three miles east of Gordon Town; Roaring River Falls. $(320,501)$

30. D. villosa (L.) Kuntze. Morce's Gap.

\section{Polystichum}

31. P. Ambiguum Maxon. Of this specimen Maxon says, "This is a puzzling form. probably referable to Polystichum ambiguum Maxon, but verging toward P. Christianae (Jenman) Maxon." Hollymount. (470) 
32. P. Christianae (Jenman) Maxon. Hollymount woods. (425)

33. P. Denticulatum (Swartz) J. Smith. Frequent along Sir John's Peak trail, $5800 \mathrm{ft}$.

34. P. Struthionis Maxon. Common along fairly open trails at Cinchona. Morce's Gap. (203)

35. P. polystichiformis (Fée) Maxon. Woods along trail to Morce's Gap. $\quad(211,623)$

36. P. RHIzophorum (Jenman) Maxon. HollymountMoneague road. (474)

37. P. triangulum (L.) Fée. Variable. On rocks at Moneague and in woods near Ewarton. (412, $444,516)$

\section{Nephrolepis}

38. N. Biserrata (Swartz) Schott. One specimen found at Moneague. (518)

39. N. cordifolia (L.) Presl. Common in open places at Cinchona. (198)

\section{Tectaria}

40. T. cicutaria (L.) Copel. Hollymount woods. (433)

41. T. CoRIANdrifolia (Swartz) Underw. HollymountMoneague road. (484)

42. T. heracleifolia (Willd.) Underw. Variable. In open woods, Ewarton. (408, 438)

43. T. martinicensis (Spreng.) Copel. Near spring, three miles north of Ewarton. (405)

\section{Camptodium}

44. C. Pedatum (Desv.) Fée. Hollymount woods. (443)

\section{ODONTOSORIA}

45. O. Jenmani Maxon. Common at Cinchona, the plants elimbing over shrubs. $(178,613,614)$ 


\section{Dennstaedtia}

46. D. cicutaria (Swartz) Moore. Large fern. Common. Morce's Gap. (282)

\section{DiPlaziUM}

47. D. centripetale Baker. Sir John's Peak trail, $5400 \mathrm{ft}$.

48. D. costale Swartz. In a shady gully near Morce's Gap (277)

49. D. seminastatum (Kunze) C. Chr. Along the trail to Morce's Gap. A most beautiful species. (218)

50. D. Wilsonir (Baker) Diels. In a shady gully near Morce's Gap. Only one specimen found.

(279)

\section{Asplenium}

51. A. abscissum Willd. Frequent at Cinchona and Hollymount. (217, 480)

52. A. alatum Humb. \& Bonpl. A marked species with its broadly winged rachis. In dense gully at Morce's Gap. (280)

53. A. Auritum Swartz. Hollymount-Moneague road. (481)

54. A. cirrhatum Rich. The fronds root at the tip as in our Camptosorus. Several well-marked varieties were collected. Cinchona. (216, 258)

55. A. Dentatum L. Along Hollymount-Moneague road. (479)

56. A. Fragrans Swartz. A delicately cut fern. Sir John's Peak trail, about $5500 \mathrm{ft}$.

57. A. PRAEMORSum Swartz. A very striking species. Searce. In dense woods along Morce's Gap trail. (300)

58. A. resillens Kunze. Cinchona, about $5000 \mathrm{ft}$. (187) 


\section{Gymnopteris}

59. G. RUFA (L.) Bernh. A soft, velvety fern. In gully near Papine. (103)

\section{LOMARIA}

60. L. Lineata (Swartz) Willd. Frequent in open parts of Sir John's Peak trail. (244)

61. L. Polypodiordes (Swartz) Desv. Sir John's Peak trail, about $5800 \mathrm{ft}$. (230)

\section{BLeChNum}

62. B. occidentale L. A very common fern found everywhere. (182)

63. B. occidentale var. minor Hook. Open places at Cinchona. (196)

\section{FILIX}

64. F. Fragilis (L.) Underw. Cinchona, near house. (311)

\section{ANOpteris}

65. A. hexagona (L.) C. Chr. In densest portions of gully in Mt. Diabolo region. (438)

\section{Adiantum}

66. A. Concinnum H.B.K. On rocky banks of road east of Gordon Town. (331)

67. A. CRistatum L. In gully near Papine. (133) A form quite different, from Hollymount, has been tentatively placed here. (413)

68. A. cuneatum $\mathrm{L}$. This has been introduced at Cinchona from Brazil. (546)

69. A. deltoideum Swartz. In crevices of rocks, Port Antonio. (537)

70. A. Fragile Swartz. Hollymount-Moneague road. (478) 
71. A. Latifolium Lam. Along roadside a mile south of Port Antonio. (535)

72. A. macrophyllum Swartz. A handsome fern with unusually broad pinnae. (565)

73. A. melanoleucum Willd. Very common along roadsides at St. Ann's Bay. A great variation exists in the size of the pinnules. (455, :98, $510,576)$

74. A. Pulverulentum L. Quite common in Hollymount woods. (410)

75. A. pulverulentum var. Caudatum Jenman. Hollymount woods.

76. A. TEnerum Swartz. Frequent at Ewarton, Moneague, and St. Ann's Bay. (395, 502, 523)

77. A. TRAPEZiforme L. A handsome fern with exceedingly large pinnules. Hollymount woods. (502a)

78. A.

sp. Apparently a distinct species but as yet undetermined. In open places near Papine. (107)

\section{HYPOLEPIS}

79. H. Nigrescens Hook. Along trail to Morce's Gap. (282a)

\section{Pityrogramma}

80. P. Calomelaena (L.) Link. Along roadside, Papine. (140)

81. P. sulphurea (Swartz) Maxon. One of the most beautiful ferns in the island, its fronds deepgreen above with yellow powder beneath. It well bears the common name of "gold fern." At frequent intervals along the Content trail from 3000 to 1500 feet. (335)

82. P. tartarea (Cav.) Maxon. A much stouter fern with white powder beneath. Common at Cinchona. (197) 


\section{Chemlanthes}

83. C. microphylla Swartz. Common in dry places. Long Mt., near Kingston; on stone fences, St. Ann's Bay. (39)

\section{Notholaena}

84. N. trichomanoides (L.) R. Br. Content trail near the Yallis River. (334a)

85. N. TRICHOMANOIDES var. SUBNUdA Jenman. On rocks in open gully east of Papine. (108)

\section{Pteris}

86. P. GRandifolia L. A large handsome once-pinnate fern with pinnae a foot long. Hollymount. (445)

87. P. Longifolia L. Common at various altitudes. Papine. (141, 250,627)

88. P. QUADRIAURITA Retz. (form). Another striking member of this genus. Newcastle, about 2700 ft. (357)

\section{Histiopteris}

89. H. INCISA (Thunb.) J. Smith. In open places along the trail to Sir John's Peak. $5400 \mathrm{ft}$. (242a)

\section{Pteridium}

90. P. Aquilinum (L.) Kuhn (form). In open places, Cinchona, forming very dense masses along the trail to Sir John's Peak. (242)

\section{Paesia}

91. P. viscosa St. Hil. Open places, Cinchona.

$(256)$

\section{Poly PODIUM}

92. P. Angustifolium Swartz. A peculiar fern with long, entire, very narrow fronds. Morce's Gap; in crevices of rocks at Hollymount. (306a, 475) 
93. P. Aureum L. var. ? One specimen found on a tree near Moneague. (454)

94. P. CRAssifolium L. A fern with entire fronds often three feet in length and a half a foot broad. Trail to Morce's Gap. (207)

95. P. CRetatum Maxon. A dainty fern found on trees on Sir John's Peak at $5800 \mathrm{ft.} \mathrm{(315)}$

96. P. cultratum Willd. Depending from trunks of trees. Margins of pinnae very ciliate. Sir John's Peak trail, $5800 \mathrm{ft}$.

97. P. curvatum Swartz. Trail to Morce's Gap. (209)

98. P. Delitescens Maxon. About an inch in height. On trees, Sir John's Peak trail, $5700 \mathrm{ft}$.

99. P. Lanceolatum L. Sir John's Peak trail, $5100 \mathrm{ft}$. (253)

100. P. Loriceum L. In open places, Cinchona, about $5000 \mathrm{ft}$.

101. P. Lycopodioides L. Winding about trunks of trees, Moneague.

102. P. marginellum Swartz. A fern with entire fronds growing in clumps on trees near the summit of Sir John's Peak. $6000 \mathrm{ft.} \quad$ (231, 319)

103. P. Myosuroides Swartz. One of the smallest ferns collected. Scarcely an inch tall. On trees near summit of Sir John's Peak.

(316a)

104. P. Pectinatum L. Along trail to Morce's Gap, about a mile north of market-place. (204)

105. P. PHyllitidis L. With long, leathery simple fronds, bearing very small fruit-dots. (428a)

106. P. Piloselloides L. Climbing over rocks near the juncture of the Hollymount and Ewarton roads. (465)

107. P. Plumula H.B.K. In open places, Cinchona. In gully near Papine. (105, 204a) 
108. P. Polypodioides (L.) A. S. Hitche. Common at lower altitudes. Papine and Long Mt., near Kingston. (37, 140)

109. P. Repens Aubl. Fronds one to two feet high. Winding about trees at Hollymount. (428)

110. P. suspensum L. Winding about trees with fronds hanging downward, forming thick masses. A very characteristic fern of the deep, cool forests along the trail up Sir John's Peak.

(226)

111. P. Trichomanoides Swartz. On trees near the summit of Sir John's Peak. (316)

\section{Oleandra}

112. O. articulata (Swartz) Presl. Fronds shiny, resembling a Polypodium. Twining about trees. Hollymount. (427)

\section{Olfersia}

113. O. Cervina (L.) Kuntze. Hollymount. (450, 426)

\section{ELAPHOGLOSSUM}

114. E. chartaceum (Baker) C. Chr. Sir John's Peak trail, $5500 \mathrm{ft}$. (241)

115. E. Cinchonae Underw. Cinchona, about 5000 ft. (206)

116. E. hirtum (Swartz) C. Chr. Thickly covered with light brown scales. On trees near summit of Sir John's Peak, $6000 \mathrm{ft.}$ (232)

117. E. Latifolium Swartz. Sir Jobn's Peak trail, $5500 \mathrm{ft.}$ (241a)

118. E. muscosum (Swartz) Moore. Morce's Gap trail. Specimens in fruit seem to be scarce. (209a)

119. E. villosum (Swartz) J. Smith. Covered with long hairs. At summit of Sir John's Peak, 6100 ft. (232a) 


\section{TRISMERIA}

120. T. trifoliata (L.) Diels. Papine: Newcastle. (110)

\section{Stenochlaena}

121. S. sp. Sterile fronds only. Hollymount. (434)

\section{Gleicheniaceae}

DicRANOPTERIS

122. D. Bancroftil (Hook.) Underw. Sir John's Peak trail, $5400 \mathrm{ft}$.

123. D. BIFIDA (Willd.) Maxon. In open places, Cinchona. (588)

124 D. Jamaicensis Underw. Open places along trail to Sir John's Peak, $5900 \mathrm{ft}$. (235)

125. D. pectinata (Willd.) Underw. Common at Cinchona. A form of this was collected, verging toward D. flexuosa. (210)

\section{Schizaeaceae}

Anemia

126. A. adiantifolia Swartz. Common along roadsides from Ewarton to St. Ann's Bay and Roaring River Falls. (441)

127. A. HiRsuta Swartz. On dry banks along roadsides from Gordon Town to Newcastle. (369)

\section{Marattiaceae}

\section{Marattia}

128. M. alata Swartz. A large fern along trail to Sir John's Peak, about 5800 ft. (219)

\section{Ophioglossaceae}

BOTRYCHIUM

129. B. DICHRonum Underw. In moist woods, Sir John's Peak trail, $5500 \mathrm{ft}$. Somewhat resembling our B. virginianum. 
130. B. Underwoodiana Maxon. One specimen found about two miles east of Cinchona. (616)

\section{Lycopodiaceae}

\section{LYCOPODIUM}

131. L. clavatum L. Common at Cinchona. (212)

132. L. Curvatum Swartz. Frequent along trail to Morce's Gap. (213b)

133. L. Fawcettii Lloyd \& Unaierw. Not common. Cinchona. (213a)

134. L. Jussiaei Desv. Two miles east of Cinchona. Along Sir John's Peak trail (204)

135. L. Reflexum Lam. Frequent at Cinchona and Newcastle. $(257,387)$

136. L. taxifolium Swartz. Bears a superficial resemblance to Ground Hemlock. Near summit of Sir John's Peak. 6000 ft. (327)

\section{Selaginellaceae}

\section{Selaginella}

137. S. didymostachya (Desv.) Spring. Trail to Morce's gap. (213d)

A large striking Selagineiia of a bluish-green color is found as an escape at Hollymount. (466)

Rochester, N. Y. 


\section{$2 \mathrm{BHL}$ Biodiversity Heritage Library}

Killip, Ellsworth P. 1917. "Ferns of Jamaica." American fern journal 7, 36-50. https://doi.org/10.2307/1544679.

View This Item Online: https://www.biodiversitylibrary.org/item/96811

DOI: https://doi.org/10.2307/1544679

Permalink: https://www.biodiversitylibrary.org/partpdf/229992

\section{Holding Institution}

Missouri Botanical Garden, Peter H. Raven Library

\section{Sponsored by}

Missouri Botanical Garden

\section{Copyright \& Reuse}

Copyright Status: Public domain. The BHL considers that this work is no longer under copyright protection.

This document was created from content at the Biodiversity Heritage Library, the world's largest open access digital library for biodiversity literature and archives. Visit BHL at https://www.biodiversitylibrary.org. 